\title{
1 Climate change suggests a shift of H5N1 risk in
}

\section{2 migratory birds}

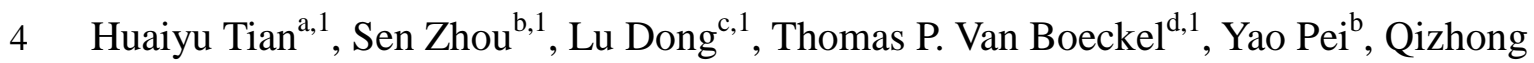

$5 \mathrm{Wu}^{\mathrm{a}}$, Wenping Yuan ${ }^{\mathrm{a}}$, Yan Guo ${ }^{\mathrm{a}}$, Shanqian Huang ${ }^{\mathrm{a}}$, Wenhuan Chen ${ }^{\mathrm{b}}$, Xueliang Lu ${ }^{\mathrm{e}}$,

6 Zhen Liu ${ }^{\mathrm{e}}$, Yuqi Bai ${ }^{\mathrm{b}}$, Tianxiang Yue ${ }^{\mathrm{f}}$, Bryan Grenfell $^{\mathrm{d}, \mathrm{g}}$, Bing Xu $^{\mathrm{a}, \mathrm{b}, \mathrm{h} *}$

${ }^{a}$ College of Global Change and Earth System Science, Beijing Normal University,

${ }^{\mathrm{b}}$ Ministry of Education Key Laboratory for Earth System Modelling, Center for Earth

System Science, and School of Environment, Tsinghua University, Beijing, 100084,

${ }^{\mathrm{c}}$ Ministry of Education Key Laboratory for Biodiversity and Ecological Engineering,

${ }^{\mathrm{d}}$ Department of Ecology and Evolutionary Biology, Princeton University, Princeton,

${ }^{\mathrm{e}}$ Center of Information and Network Technology, Beijing Normal University, Beijing,

${ }^{\mathrm{f}}$ Institute of Geographic Sciences and Natural Resources Research, Chinese Academy 
${ }^{\mathrm{g}}$ Fogarty International Center, National Institutes of Health, Bethesda, MD 20892,

${ }^{1}$ Author contributed equally

* Corresponding author. Tel: +86-13801315199 


\section{Abstract}

Migratory birds are considered to have played an important role in the spread of highly pathogenic avian influenza H5N1. However, how bird species are expected to modify their wintering sites in response to climate change, and in turn affect the geographic distribution of the risk associated with H5N1 outbreaks, is unknown. We explored the association between past climate variability and $\mathrm{H} 5 \mathrm{~N} 1$ outbreaks that were attributed to migratory birds from 2005 to 2009 . We then predicted the distribution of risk associated with $\mathrm{H} 5 \mathrm{~N} 1$ outbreaks based on future climate change scenarios. Overlapping the probabilities of bird distribution and H5N1 outbreaks produced final emergence risk. Our results suggest that minimum daily temperature in the winter $\left(-15--11^{\circ} \mathrm{C}, 15-17^{\circ} \mathrm{C}\right)$ and maximum daily temperature in the summer $\left(12-15^{\circ} \mathrm{C}, 30-35^{\circ} \mathrm{C}\right)$ governed wild bird migratory routes, while high mean air pressure and low mean specific humidity in the winter impacted the outbreaks of H5N1 among migratory birds. By the end of 2030, Europe may be at higher risk for H5N1 outbreaks in January and February. Northern Africa and Southern and Western Asia will likely be a higher risk for H5N1 outbreaks from April to June. Our findings suggest a potential shift in $\mathrm{H} 5 \mathrm{~N} 1$ risk from Southeast Asia to the western part of the world due to climate change. The results of this study could be used to inform policy in the area of $\mathrm{H} 5 \mathrm{~N} 1$ outbreak detection and preparedness.

Keywords: Climate change; avian influenza; H5N1; migratory birds 


\section{Introduction}

Highly pathogenic avian influenza (HPAI) A subtype H5N1 virus was first isolated from a goose farm in Guangdong Province, China in 1996 (Claas et al., 1998). It is epizootic in several bird species, principally across Southeast Asia (Webster, 2004).

Clade 2.2 of the virus spread globally throughout Europe, the Middle East and Africa after first appearing in Asia in 2005 (Chen et al., 2006; Webster and Govorkova, 2006; Scotch et al., 2013; Li et al., 2014). Because of the high lethality and virulence of $\mathrm{H} 5 \mathrm{~N} 1$, its endemic presence, its increasingly large host reservoir, and its significant rate of mutation, it is currently one of the world's greatest pandemic threats (Gambotto et al., 2008; Tsang et al., 2005).

It is commonly accepted that migratory birds are the natural reservoir of influenza A viruses, and waterfowl are the primary reservoir of low-pathogenic avian influenza (LPAI) viruses (Olsen et al., 2006). Evidence supporting the role of migratory birds in the spread of HPAI H5N1, especially the Anseriformes and Charadriiformes, emerged when almost 10,000 migratory birds infected with H5N1 died at the Qinghai Lake nature reserve in central China in 2005, and a series of outbreaks occurred in Europe in early 2006 (Chen et al., 2005). Based on the whole-genome analyses of low pathogenic avian influenza isolates collected in Alaska from the northern pintail (Anas acuta), which migrates between North America and Asia, phylogenetic analysis suggested that wild birds could transfer influenza viruses (AIVs) intercontinentally (Koehler et al., 2008).

HPAI H5N1-infected migratory birds have been found in several European countries, but local outbreaks were smaller in size and intensity compared with the situation observed in China and Southeast Asia (Globig et al., 2009; Ward et al., 2008). This pattern suggests that some wild birds are able to spread AIVs over long distances 
to previously unaffected areas (Olsen et al., 2006). In experimental studies, wild species of ducks, geese and swans have shown the ability to replicate and shed H5N1 for several days without showing clinical or pathologic signs of disease (Kim et al., 2009). Among the species studied, mallards (Anas platyrhynchos), mute swans (Cygnus olor), cackling geese (Branta hutchinsii), and bar-headed geese (Anser indicus) pose a greater risk for HPAI H5N1 transmission (Brown et al., 2006; Brown et al., 2008a, b; Keawcharoen et al., 2008). Some wild birds may be partially immune to HPAI H5N1 due to previous exposure to LPAI viruses (Seo et al., 2002). Specifically, a previous infection with subtype H9N2 could confer partial protection against HPAI H5N1 (Khalenkov et al., 2009). Data obtained by satellite telemetry revealed that white-faced whistling ducks (Dendrocygna viduata) survived HPAI $\mathrm{H} 5 \mathrm{~N} 2$ infection and were able to migrate for at least $655 \mathrm{~km}$. This finding suggests that long distance dispersal of HPAI H5N2 by migratory ducks is possible (Munster and Fouchier, 2009). Based on one of the largest datasets available for migratory and resident wild birds sampled on HPAI H5N1 infection in Thailand, a nonhomogeneous birth and death statistical model was used to reveal the relationship between poultry and wild bird outbreaks. The result indicated that the transmission efficiency of HPAI H5N1 among poultry was 1.7 times higher in regions where infected wild birds had been detected compared with regions without infected wild birds (Keawcharoen et al., 2011). In addition, waterfowl may transfer the virus mechanically during long distance migration, and feathers infected with HPAI H5N1 could also be a source of environmental contamination with high viral loads (Uriarte et al., 2011; Yamamoto et al., 2010).

Climate change is likely to influence the geographical distribution and transmission intensity of disease (Gething et al., 2010; Wu et al., 2014). Satellite 
imagery, global climate models (GCM), meteorological data, and species distribution models can be used in combination to predict the future distribution of disease vectors and hosts (Michishita et al., 2012a; Michishita et al., 2012b; Xu et al., 2004; Xu et al., 2006).

\section{Climate change may additionally influence HPAI H5N1 evolution and host} behaviour, thereby modifying the periodicity, prevalence, and intensity of HPAI H5N1 transmission (Herrick et al., 2013). On one hand, several studies have shown that climate conditions and climate indices can influence the timing of migration and the distribution of migratory birds (Cotton, 2003; Forchhammer et al., 2002; Sillett et al., 2000). Among these variables, temperature was found to have a strong statistical correlation with bird distribution (Root, 1988; Root and Schneider, 1993). In particular, winter temperatures are closely associated with waterfowl movement. The congregation of waterfowl along the $0^{\circ} \mathrm{C}$ isotherm likely contributed to the geographical spread of HPAI H5N1 outbreaks in migratory birds in Europe during the winter of 2005-2006 (Reperant et al., 2010). On the other hand, it has been shown that AIVs can persist for an extended period of time in water, especially at low temperatures (Brown et al., 2009; Brown et al., 2007; Stallknecht et al., 1990). In extremely cold conditions, high-energy expenditure and limited access to food can also make potential hosts more susceptible to AIVs. Predicting the impact of climate change on the distribution of HPAI H5N1 outbreak risks will inform disease prevention policy and preparedness.

In this study we explored the potential impact of climate change on the distribution of HPAI H5N1 infection risk in three steps. First, we investigated the impact of climate on the spatial distribution of migratory birds and the occurrence of H5N1 outbreaks among migratory birds. Second, the monthly spatial distribution of 
migratory birds and H5N1 outbreaks were derived and estimated globally based on the current climate. Finally, we used future climate scenarios based on conservative greenhouse gas emissions to predict the risk of HPAI H5N1 outbreaks among migratory birds for each month and construct global risk maps up until the year 2030 .

\section{Material and Methods}

\subsection{HPAI H5N1 outbreak data}

HPAI H5N1 outbreak data from 2005-2009 were obtained from the Food and Agriculture Organization (FAO) of the United Nations and the World Organization for Animal Health (OIE). The data include the date and location of the outbreak, the subtype of AIV, and the host species (domestic or wild). To build an integrated dataset, we combined the two data sources and removed all duplicate reports. Our dataset included 902 independent records of outbreaks in wild birds spanning from January 2005 to April 2009.

An HPAI H5N1 outbreak in wild birds is defined as one or more cases of HPAI $\mathrm{H} 5 \mathrm{~N} 1 \mathrm{in}$ wild birds within a $100 \mathrm{~km}$ area that was free of HPAI H5N1 outbreaks in poultry in the current and preceding months (Reperant et al., 2010). Using this definition, wild bird outbreaks that may have resulted from an infected poultry outbreak were excluded. Data were pooled by calendar month.

\subsection{Migratory bird data}

Data on wild bird migration and migration paths were derived from the work of Gaidet et al. (Gaidet et al., 2010) from United States Geological Survey (USGS), the Raptor Research Group of Taiwan (RRGT) and the Royal Society for the Protection of Birds (RSPB). This geocoded data include migratory bird ringing and satellite 
tracking data. The migration flyways covered in this study are the Black Sea/Mediterranean Flyway, the East Asian-Australasian Flyway, the Central Asian flyway and the West Asian-East African Flyway. Data were pooled by calendar month.

\subsection{Climate data}

The Modern Era Retrospective-Analysis for Research and Applications (MERRA) dataset is a re-analysis climate database managed by the NASA Goddard Earth Observing System Data Assimilation System Version 5 (GEOS-5). The MERRA climate data are generated by combining all available global surface observations every 3 hours and interpolating the results to a continuous surface. It produces estimates of global climate variables ten meters above the land surface, with a resolution of $0.5^{\circ}$ latitude by $0.6^{\circ}$ longitude. Daily averages of surface incident shortwave flux (radiation), air temperature, specific humidity, precipitation, and air pressure were used in this study. The 5-year monthly mean temperature, monthly standard deviation of temperature, mean minimum temperature, mean maximum temperature, monthly cumulative precipitation, mean air pressure, mean specific humidity and monthly cumulative radiation were calculated on a global scale.

To derive robust estimates of future climate conditions, we used the climate projections (Table S1) derived from downscaled monthly outputs of 20 different global circulation models (GCMs) (Table S2), based on the Representative Concentration Pathways (RCP) 4.5 emission scenario. We used the year 2030 as the reference year for prediction of the same climate variables extracted from the MERRA dataset. 


\subsection{Risk estimation and risk prediction}

We used the maximum entropy (MAXENT, (Phillips et al., 2006)) algorithm to evaluate the impact of climate on wild bird migration and HPAI H5N1 outbreaks from 2005 to 2009. This methodology based on presence-only records has been used successfully to predict the distribution of HPAI H5N1 in Asia (Stevens et al., 2013).

To assess the accuracy of the model, we used a 'K-folds' cross-validation approach to randomly sample occurrences from each dataset for training runs. We used the remaining occurrences to test the model. For our models, the cross-validation process was repeated 10 times. The outbreak data from 2005 to 2009 were randomly split into 10 equally sized groups. Each one of the groups was used exactly once as validation data, and the remaining 9 groups were used as training data. The accuracy of the prediction was evaluated using average of the area under the curve (AUC) for the receiver operating characteristic (ROC) curves. Model accuracy using AUC was characterized as $0.60-0.70$, poor; $0.70-0.80$, average; $0.80-0.90$, good; $0.90-1$, excellent.

The final predictive model depends only on the final Maxent model. The climate variables extracted from the GCMs using the RCP4.5 scenario for the year 2030 were used as input data for the final predictive model. The final distribution of risk estimates was obtained by combining the distributions of probability of the presence of migratory birds with the probability of presence of HPAI H5N1 outbreaks. The predictions derived from each of the $20 \mathrm{GCMs}$ were combined into a single output layer representing the average of the future risk map.

Here, $x$ is a random site in the study area denoted as $X$. Each $x$, contains a constant of either 1 or 0 which is defined by the presence or absence of the species / outbreak under study. The probability distribution of the species / outbreak is based on 
the maximum entropy density estimation. The primary output "raw output" is as follows:

$$
q_{\lambda}(x)=\frac{\exp \left(\sum_{i=1}^{n} \lambda_{i} f_{i}(x)\right)}{Z_{\lambda}}
$$

The features $f$ ranging from $f_{1}, f_{2}, \ldots \ldots f_{\mathrm{n}}$ are functions which were derived from environmental variables. These functions are affected by six classes of features that include linear, quadratic, product, threshold, hinge, and category indicator features. $\lambda=\left(\lambda_{1}, \lambda_{2}, \ldots . . \lambda_{n}\right)$ are feature weights. $Z_{\lambda}$ is a scaling constant that ensures that $q_{\lambda}(x)$ sums to 1 over the whole study area, and $H$ is the entropy of $q_{\lambda}(x)$. The logistic output format of the MAXENT model was chosen to give an estimate of the probability presence $(\mathrm{P})$ :

(1)

$$
\mathrm{P}=\frac{q_{\lambda}(x) \times e^{H}}{1+q_{\lambda}(x) \times e^{H}}
$$

$H=-\sum q_{\lambda}(x) \ln \left(q_{\lambda}(x)\right)$

$$
\mathrm{P}_{\text {risk }}=\sqrt{\mathrm{P}_{\text {bird-distribution }} \times \mathrm{P}_{\text {outbreak }}}
$$

Jack-knife procedure and permutation importance are used to measure variable contribution depending on the best-fitting model. The contribution for each variable is determined by randomly permuting the values of that variable among the training 
points (both presence and background) and measuring the resulting decrease in training AUC when the corresponding variables are not used. A large decrease indicates that the model depends heavily on that variable. Values of permutation importance are normalized to give percentages. The normalized values of permutation importance give a more relative ranking of variable importance, helping to control for correlations between variables.

\section{Results}

\subsection{Impact of climate on wild bird migration}

A strong correlation was observed between the predicted and observed monthly distributions of migratory birds, with most observations falling in the high-probability area (Figure 1). For each of the 10 replicates of the 12 monthly models, AUC were greater than 0.9 (Table 1), indicating that the model performed well. The relative importance of each variable (Figure 2) contributing to the present distribution of migratory birds was evaluated using a jack-knife plot of the AUC. Temperature and radiation fit reasonably well with the AUC, indicating they provided the most useful information. Variations in temperature, however, provided little gain (Figure 2).

Table 2 explains the association between climate and the distribution of migratory birds. Due to sample heterogeneity, climate, and variety of bird species, the relationship is not unimodal and may vary with season. One interesting finding is that during spring migration and wintering, the mean minimum temperature (MinT) was a more important factor than the mean maximum temperature (MaxT) or the mean temperature (MT) in explaining the distribution of birds. The permutation importance of the mean minimum temperature from December to March was larger than $40 \%$, and from April to November was larger than 30\%. During the breeding period, 
however, maximum temperature was the most important factor; the permutation importance of mean maximum temperature was larger than $40 \%$. Temperature played a fundamental role in bird migration and distribution. From December to April, the temperature that made a high contribution to explaining the distribution of migratory birds ranged from $-18^{\circ} \mathrm{C}$ to $0^{\circ} \mathrm{C}$ and $12^{\circ} \mathrm{C}$ to $24^{\circ} \mathrm{C}$, while from June to July, mean maximum temperatures ranged from $12^{\circ} \mathrm{C}$ to $25^{\circ} \mathrm{C}$ and $30^{\circ} \mathrm{C}$ to $37^{\circ} \mathrm{C}$.

\subsection{Linking climate variability with HPAI H5N1 outbreaks.}

The average AUC for the 10 replicates of the 12 monthly models was higher than 0.9 for all months except June (ROC: 0.755), indicating that the model performed well (Table 1, Figure 3). The number of outbreaks in September was insufficient to train the model. The relative importance of each variable determined by the jack-knife method (Figure 4) was similar to the predicted bird distribution during migration (Figure 2). Temperature and radiation were the most important factors from February to August, and air pressure became important in the winter (October to December). The response curves indicated associations between the probability of an HPAI $\mathrm{H} 5 \mathrm{~N} 1$ outbreak in migratory birds and variation in each climatic variable (Table 3). Mean minimum temperatures in the range of $-2{ }^{\circ} \mathrm{C}$ to $-1{ }^{\circ} \mathrm{C}$ during spring migration (March and April), mean specific humidity $\left(7.2 \mathrm{~g} / \mathrm{m}^{3}-8.8 \mathrm{~g} / \mathrm{m}^{3}\right)$ and precipitation (40 $\mathrm{mm}-60 \mathrm{~mm}$ ) in July and August, and mean air pressure in the range of $1000 \mathrm{hPa}$ to $1026 \mathrm{hPa}$ from October to December are factors associated with the risk of an outbreak. For the months of February $\left(2800 \mathrm{Wm}^{-2}-3200 \mathrm{Wm}^{-2}\right)$, March (4000 $\left.\mathrm{Wm}^{-2}-4100 \mathrm{Wm}^{-2}\right)$, May $\left(10500 \mathrm{Wm}^{-2}-11300 \mathrm{Wm}^{-2}\right)$, July $\left(7200 \mathrm{Wm}^{-2}\right)$ and August $\left(10200 \mathrm{Wm}^{-2}-10300 \mathrm{Wm}^{-2}\right)$, radiation levels are also closely associated with the risk of an outbreak. 


\subsection{Areas with high potential risk}

By combining the predictions of migratory bird distribution and HPAI H5N1 outbreak, we found that during the wintering period from December to February, the combined risk was concentrated in Southeast Asia, southern China and India. In March, April and May, the high-risk area shifted north to the range of $30^{\circ}$ to $55^{\circ} \mathrm{N}$, and mainly included Northeast China, the Qinghai-Tibet area and Europe. In the breeding period from June to August, the highest risk areas were located in Mongolia, Western Europe, Russia and Siberia (Figure 5).

\subsection{Forecasting risk prediction under a changing climate}

Based on the future climate change scenario we have identified that the main regions at risk for H5N1 HPAI outbreaks are located in Europe from January to February, in the Qinghai-Tibet area and northern Africa at the same latitude from April to July, and in Southeast Asia, South China and Central Asia from November to December. These results are consistent with the predicted distribution of migratory birds (Figure S1, Figure S2). The uncertainty analysis indicates that migratory birds and outbreaks of HPAI H5N1 are homogenously distributed in most regions (Figure S3, Figure S4) with the exception of outbreak predictions during the months of September and November in some local regions. This inconsistency in the findings may be due to the lack of training data for the months of September and November (Figure S4).

Based on the migratory bird distribution and HPAI H5N1 outbreak predictions under the possible future scenarios for global climate (Figures S5-S24), we found that Europe, Japan and South China may become high-risk regions for HPAI H5N1 outbreaks from January to February (Figure 6). In contrast, North Africa, West Asia and Central Asia may become high-risk areas from April to June. The west coast of Africa, the east coast of Africa, West Asia, India and South China may be at high risk 
after October. Compared with the current pattern of high-risk areas, the high-risk areas in Africa will shift from the centre of the continent to the north. In addition, the high-risk area in winter is likely to expand from lower-latitude to higher-latitude areas.

\section{Discussion}

To date, little is known about the potential impact of climate change on the transmission and persistence of HPAI H5N1 (Herrick et al., 2013). In general terms, species distribution, migratory routes and behaviour of migratory birds are highly dependent upon climatic conditions, especially for long-distance migratory birds subject to seasonal variation in food availability (Both et al., 2010; Gilbert et al., 2008; Jonzén et al., 2006). Rising global temperatures may impact substantially the geographical distribution of migratory birds and the diseases they carry, including HPAI H5N1. Changes in migratory pathways, breeding behaviour, wintering and stopover sites may lead to the emergence of new enzootic areas and constitute major threats to the poultry industry in regions overlapping with migratory flyways.

Using satellite tracking data, we were able to investigate the potential impact of climate change on the distribution of migratory birds (Gschweng et al., 2012; Visser et al., 2009). From Figure S2, we have identified a seasonal trend in the risk of HPAI H5N1 outbreaks. A general shift in the distribution of migratory birds toward higher latitudes during winter or breeding season in the Northern hemisphere may have two consequences. First, a warmer winter will result in wintering grounds that are closer to breeding areas of migratory birds in the Northern hemisphere. Thus long-distance migrants may become short-distance migrants (Liu et al., 2012), and this behaviour change is likely to increase population mixing in the winter. This effect might be 
further increased in the case of high-risk species displaying fidelity to their breeding sites; e.g. tufted duck in Eurasia (Tøttrup et al., 2012). Second, prolonged stays at breeding sites in Europe, Siberia, and the Qinghai-Tibet plateau will also increase the risk of HPAI H5N1 in these areas.

Mean maximum temperature restricts the distribution of migratory birds during the breeding period and the mean minimum temperature restricts distribution during the wintering period. These findings are consistent with the results of previous studies (Root et al., 2003; Thomas and Lennon, 1999). A potential limitation of this study is that while the satellite tracking and outbreak data comprise two independent datasets, the data collection periods are not identical. The earliest satellite tracking data were collected from 2006, and did not include all the bird species uniformly, whereas the majority of the outbreak data $(95.15 \%, 980 / 1130)$ were collected between 2005 and 2007.

Impacted by climate change, migratory birds will make a northerly shift from their current distribution to adapt to the global climate of the future (Both et al., 2006). These changes will lead to different patterns of HPAI H5N1 transmission and outbreaks among migratory birds. On one hand, due to more frequent winter mixing of migratory birds in traditional breeding and wintering areas (Hitch and Leberg, 2006; MARINI et al., 2009), some species may change their role from long- to short-distance transmitters in new geographic areas. On the other hand, migration flyways may also be influenced by climate change, and new areas impacted by HPAI H5N1 outbreaks may emerge. HPAI H5N1 outbreaks in migratory birds are highly correlated with migratory bird distributions, which in turn are significantly influenced by climatic conditions (Prosser et al., 2011). Assessing the potential shift of certain migration flyways and the resultant 
change in HPAI H5N1 risk is a difficult and highly speculative task because the link between climate and migration routes is complex (Robinson et al., 2009). Besides, habitat / land cover determines where migratory birds are distributed and oriented during migration. It could further reduce predicted distribution area based on the seasonal distribution trend. Combining wild bird $\mathrm{H} 5 \mathrm{~N} 1$ infection data with satellite tracking data (Gaidet et al., 2010), it is possible to identify high-risk bird species that have the potential to spread the virus over long distances. It is of vital importance to identify potentially high-risk areas to improve surveillance for HPAI H5N1 outbreaks in migratory birds. Our results indicate that Europe, North Africa and West Asia will be at higher risk for H5N1 HPAI outbreaks in migratory birds by 2030. Additionally, our findings suggest that high-risk areas in Europe will expand geographically. Whether this potential increase in risk of outbreaks in migratory birds will influence the risk of outbreaks in European poultry is an important research question. Our results indicate that West Asia will also become a high-risk area, although few HPAI H5N1 cases have been reported in West Asia up until now. Furthermore, the vulnerability of this region may be underestimated because of inadequate surveillance, and therefore the importance of migratory birds to this region may have been overlooked up until now. Low income countries with poor veterinary and surveillance infrastructure such as Nigeria and Egypt have suffered substantially from endemic HPAI H5N1 in poultry (Meleigy, 2007). Based on the predictions made in this study, this situation may worsen because areas will be subjected to a higher risk of outbreaks due to migratory birds. The risk areas may expand and cover almost all of North Africa.

Some limitations of this study should be acknowledged. First, although current satellite tracking data covers most of the worldwide flyways and has been deemed 
representative, the majority of collected samples come from the Asian Flyway. This may represent a type of sampling bias. Second, the uncertainty of global climate predictions based on retrospective data is important. This limitation has led to debate about prediction application, in particular, whether the scenario analysis can be assessed based on valid baseline conditions (Barnett, 1999). Third, the outbreak data were collected from a passive surveillance system. Therefore, these data may not be representative of the actual burden of HPAI H5N1 in countries where routine reporting is low; e.g. important difference in reporting are suspected between Asia and Europe. The reported outbreaks in migratory birds are concentrated in Europe, accounting for $89 \%$ (919/1030) of all data. Some outbreaks might also go unreported in Asia and Africa, leading to more bias in data collection. Finally, we did not take anthropogenic factors, such as HPAI H5N1 control measures, into consideration. As interventions play a role in preventing dissemination of $\mathrm{H} 5 \mathrm{~N} 1$ virus, further outbreak may be prevented by a comprehensive surveillance and outbreak management. Furthermore, anthropogenic environment is considered as another fundamental driver for the HPAI H5N1 persistence. Production habit and human argo-ecological condition could have influence on the maintaining and dispersing of HPAI H5N1 (Rivas et al., 2010).

Climate change will likely affect the global distribution of the risk associated with HPAI H5N1 through changing migratory flyways and species mixing during wintering and breeding, with the result being an increase in virus transmission. Our model, which was validated against empirical data, has identified strong associations between climatic variables, the distribution of migratory birds, and the risk of HPAI H5N1. The results of this study highlight the need for HPAI H5N1 outbreak detection and preparedness in places where there have been few reported cases of HPAI H5N1, 
especially in developing countries that are most vulnerable to the impacts of climate

404 change.

405

National Research Program (2010CB530300, 2012CB955501, 2012AA12A407, 2013AA122003), and the National Natural Science Foundation of China (41271099).

410 Grenfell is supported by the Science and Technology Directorate, Department of

411 Homeland Security contract HSHQDC-12-C-00058, the Bill and Melinda Gates

412 Foundation and the RAPIDD program of the Science and Technology Directorate, U.S.

413 Department of Homeland Security, and the Fogarty International Center, NIH. The

414 funders had no role in the study design, data collection and analysis, decision to

415 publish, or preparation of the manuscript.

416

417

418

419

420 


\section{References}

Barnett, T., 1999. Comparison of near-surface air temperature variability in 11 coupled global climate models. J Climate 12, 511-518.

Both, C., Bouwhuis, S., Lessells, C., Visser, M.E., 2006. Climate change and population declines in a long-distance migratory bird. Nature 441, 81-83.

Both, C., Van Turnhout, C.A.M., Bijlsma, R.G., Siepel, H., Van Strien, A.J., Foppen, R.P.B., 2010. Avian population consequences of climate change are most severe for long-distance migrants in seasonal habitats. Proc R Soc B 277, 1259-1266.

Brown, J.D., Goekjian, G., Poulson, R., Valeika, S., Stallknecht, D.E., 2009. Avian influenza virus in water: infectivity is dependent on $\mathrm{pH}$, salinity and temperature. Vet Microbiol 136, 20-26.

Brown, J.D., Stallknecht, D.E., Beck, J.R., Suarez, D.L., Swayne, D.E., 2006. Susceptibility of North American ducks and gulls to H5N1 highly pathogenic avian influenza viruses. Emerg Infect Dis 12, 1663-1670.

Brown, J.D., Stallknecht, D.E., Swayne, D.E., 2008a. Experimental infection of swans and geese with highly pathogenic avian influenza virus (H5N1) of Asian lineage. Emerg Infect Dis 14, 136-142. Brown, J.D., Stallknecht, D.E., Swayne, D.E., 2008b. Experimental infections of herring gulls (Larus argentatus) with H5N1 highly pathogenic avian influenza viruses by intranasal inoculation of virus and ingestion of virus-infected chicken meat. Avian Pathol 37, 393-397.

Brown, J.D., Swayne, D.E., Cooper, R.J., Burns, R.E., Stallknecht, D.E., 2007. Persistence of H5 and $\mathrm{H} 7$ avian influenza viruses in water. Avian Dis 51, 285-289.

Chen, H., Smith, G.J., Li, K.S., Wang, J., Fan, X.H., Rayner, J.M., Vijaykrishna, D., Zhang, J.X., Zhang, L.J., Guo, C.T., Cheung, C.L., Xu, K.M., Duan, L., Huang, K., Qin, K., Leung, Y.H., Wu, W.L., Lu, H.R., Chen Y, X.N., Naipospos TS, Yuen KY, Hassan SS, Bahri S, Nguyen TD, Webster RG, Peiris JS, Guan Y., 2006. Establishment of multiple sublineages of H5N1 influenza virus in Asia: Implications for pandemic control. Proc Natl Acad Sci USA 103, 2845-2850.

Chen, H., Smith, G.J., Zhang, S.Y., Qin, K., Wang, J., Li, K.S., Webster, R.G., Peiris, J.S., Guan, Y., 2005. Avian flu: H5N1 virus outbreak in migratory waterfowl. Nature 436, 191-192.

Claas, E.C.J., Osterhaus, A.D.M.E., van Beek, R., De Jong, J.C., Rimmelzwaan, G.F., Senne, D.A., Krauss, S., Shortridge, K.F., Webster, R.G., 1998. Human influenza A H5N1 virus related to a highly pathogenic avian influenza virus. Lancet 351, 472-477.

Cotton, P.A., 2003. Avian migration phenology and global climate change. Proc Natl Acad Sci USA 100, 12219-12222.

Forchhammer, M.C., Post, E., Stenseth, N.C.H.R., 2002. North Atlantic Oscillation timing of long-and short-distance migration. J Anim Ecol 71, 1002-1014.

Gaidet, N., Cappelle, J., Takekawa, J.Y., Prosser, D.J., Iverson, S.A., Douglas, D.C., Perry, W.M., Mundkur, T., Newman, S.H., 2010. Potential spread of highly pathogenic avian influenza H5N1 by wildfowl: dispersal ranges and rates determined from large-scale satellite telemetry. J Appl Ecol 47, 1147-1157.

Gambotto, A., Barratt-Boyes, S.M., de Jong, M.D., Neumann, G., Kawaoka, Y., 2008. Human infection with highly pathogenic H5N1 influenza virus. Lancet 371, 1464-1475.

Gething, P.W., Smith, D.L., Patil, A.P., Tatem, A.J., Snow, R.W., Hay, S.I., 2010. Climate change and the global malaria recession. Nature 465, 342-345.

Gilbert, M., Slingenbergh, J., Xiao, X., 2008. Climate change and avian influenza. Rev Sci Tech 27, 459-466.

Globig, A., Staubach, C., Beer, M., Köppen, U., Fiedler, W., Nieburg, M., Wilking, H., Starick, E., Teifke, J., Werner, O., 2009. Epidemiological and ornithological aspects of outbreaks of highly pathogenic avian influenza virus H5N1 of Asian lineage in wild birds in Germany, 2006 and 2007. Transbound Emerg Dis 56, 57-72.

Gschweng, M., Kalko, E.K.V., Berthold, P., Fiedler, W., Fahr, J., 2012. Multi-temporal distribution modelling with satellite tracking data: predicting responses of a long-distance migrant to changing environmental conditions. J Appl Ecol 49, 803-813. Herrick, K.A., Huettmann, F., Lindgren, M.A., 2013. A global model of avian influenza prediction in wild birds: the importance of northern regions. Vet Res 44, 42.

Hitch, A.T., Leberg, P.L., 2006. Breeding distributions of North American bird species moving north as a result of climate change. Conserv Biol 21, 534-539.

Jonzén, N., Lindén, A., Ergon, T., Knudsen, E., Vik, J.O., Rubolini, D., Piacentini, D., Brinch, C., Spina, 
F., Karlsson, L., 2006. Rapid advance of spring arrival dates in long-distance migratory birds. Science 312, 1959-1961.

Keawcharoen, J., van den Broek, J., Bouma, A., Tiensin, T., Osterhaus, A.D.M.E., Heesterbeek, H., 2011. Wild birds and increased transmission of highly pathogenic avian influenza (H5N1) among poultry, Thailand. Emerg Infect Dis 11, 1016-1022.

Keawcharoen, J., Van Riel, D., Van Amerongen, G., Bestebroer, T., Beyer, W.E., Van Lavieren, R., Osterhaus, A.D.M.E., Fouchier, R.A.M., Kuiken, T., 2008. Wild ducks as long-distance vectors of highly pathogenic avian influenza virus (H5N1). Emerg Infect Dis 14, 600-607.

Khalenkov, A., Perk, S., Panshin, A., Golender, N., Webster, R.G., 2009. Modulation of the severity of highly pathogenic H5N1 influenza in chickens previously inoculated with Israeli H9N2 influenza viruses. Virology 383, 32-38.

Kim, J.K., Negovetich, N.J., Forrest, H.L., Webster, R.G., 2009. Ducks: the "Trojan horses" of H5N1 influenza. Influenza Other Respir Viruses 3, 121-128.

Koehler, A.V., Pearce, J.M., Flint, P.L., Franson, J.C., Ip, H.S., 2008. Genetic evidence of intercontinental movement of avian influenza in a migratory bird: the northern pintail (Anas acuta). Mol Ecol 17, 4754-4762.

Li, R., Jiang, Z., Xu, B., 2014. Global spatiotemporal and genetic footprint of the H5N1 avian influenza virus. International Journal of Health Geographics 13(1):14.

Liu, Y., Keller, I., Heckel, G., 2012. Breeding site fidelity and winter admixture in a long-distance migrant, the tufted duck (Aythya fuligula). Heredity 109, 108-116.

MARINI, M.Â., BARBET-MASSIN, M., LOPES, L.E., Jiguet, F., 2009. Predicted climate-driven bird distribution changes and forecasted conservation conflicts in a neotropical savanna. Conserv Biol 23, 1558-1567.

Meleigy, M., 2007. Egypt battles with avian influenza. Lancet 370, 553-554.

Michishita, R., Jiang, Z., Gong, P., Xu, B., 2012a. Bi-scale analysis of multitemporal land cover fractions for wetland vegetation mapping. ISPRS J Photogramm Remote Sens 72, 1-15.

Michishita, R., Jiang, Z., Xu, B., 2012b. Monitoring two decades of urbanization in the Poyang Lake area, China through spectral unmixing. Remote Sens Environ 117, 3-18.

Munster, V.J., Fouchier, R.A., 2009. Avian influenza virus: of virus and bird ecology. Vaccine 27, 6340-6344.

Olsen, B., Munster, V.J., Wallensten, A., Waldenstrom, J., Osterhaus, A.D., Fouchier, R.A., 2006.

Global patterns of influenza A virus in wild birds. Science 312, 384-388.

Phillips, S.J., Anderson, R.P., Schapire, R.E., 2006. Maximum entropy modeling of species geographic distributions. Ecol Model 190, 231-259.

Prosser, D.J., Cui, P., Takekawa, J.Y., Tang, M., Hou, Y., Collins, B.M., Yan, B., Hill, N.J., Li, T., Li, Y., 2011. Wild bird migration across the Qinghai-Tibetan plateau: a transmission route for highly pathogenic H5N1. PLoS ONE 6, e17622.

Reperant, L.A., Fučkar, N.S., Osterhaus, A.D.M.E., Dobson, A.P., Kuiken, T., 2010. Spatial and temporal association of outbreaks of H5N1 influenza virus infection in wild birds with the $0 \mathrm{C}$ isotherm. PLoS Pathog 6, e1000854.

Rivas, A.L., Chowell, G., Schwager, S., Fasina, F.O., Hoogesteijn, A.L., Smith, S.D., Bisschop, S.P., Anderson, K., Hyman, J.M., 2010. Lessons from Nigeria: the role of roads in the geo-temporal progression of avian influenza (H5N1) virus. Epidemiol Infect 138, 192-198.

Robinson, A., Crick, H.Q.P., Learmonth, J.A., Maclean, I.M.D., Thomas, C.D., Bairlein, F., Forchhammer, M.C., Francis, C.M., Gill, J.A., Godley, B.J., 2009. Travelling through a warming world: climate change and migratory species. Endangered Species Research 7, 87-99.

Root, T., 1988. Environmental factors associated with avian distributional boundaries. J Biogeogr 1, 489-505.

Root, T.L., Price, J.T., Hall, K.R., Schneider, S.H., Rosenzweig, C., Pounds, J.A., 2003. Fingerprints of global warming on wild animals and plants. Nature 421, 57-60.

Root, T.L., Schneider, S.H., 1993. Can Large-Scale Climatic Models Be Linked with Multiscale Ecological Studies? Conserv Biol 7, 256-270.

Scotch, M., Mei, C., Makonnen, Y.J., Pinto, J., Ali, A., Vegso, S., Kane, M., Sarkar, I.N., Rabinowitz, P., 2013. Phylogeography of influenza A H5N1 clade 2.2. 1.1 in Egypt. BMC Genomics 14, 871. Seo, S.H., Peiris, M., Webster, R.G., 2002. Protective cross-reactive cellular immunity to lethal A/Goose/Guangdong/1/96-like H5N1 influenza virus is correlated with the proportion of pulmonary CD8+ T cells expressing gamma interferon. J Virol 76, 4886-4890.

Sillett, T.S., Holmes, R.T., Sherry, T.W., 2000. Impacts of a global climate cycle on population dynamics of a migratory songbird. Science 288, 2040-2042. 

viruses in water. Avian Dis 34, 406-411. Stevens, K.B., Gilbert, M., Pfeiffer, D.U., 2013. Modeling habitat suitability for occurrence of highly pathogenic avian influenza virus $\mathrm{H} 5 \mathrm{~N} 1$ in domestic poultry in Asia: A spatial multicriteria decision analysis approach. Spat Spatiotemporal Epidemiol 4, 1-14. C., Alerstam, T., Thorup, K., 2012. Drought in Africa Caused Delayed Arrival of European Songbirds. Science 338, 1307-1307.

Thomas, C.D., Lennon, J.J., 1999. Birds extend their ranges northwards. Nature 399, 213-213.

Tsang, K.W.T., Eng, P., Liam, C., Shim, Y., Lam, W.K., 2005. H5N1 influenza pandemic: contingency plans. Lancet 366, 533-534. Uriarte, M., Anciães, M., da Silva, M.T., Rubim, P., Johnson, E., Bruna, E.M., 2011. Disentangling the drivers of reduced long-distance seed dispersal by birds in an experimentally fragmented landscape. Ecology 92, 924-937.

Visser, M.E., Perdeck, A.C., van Balen, J.H., Both, C., 2009. Climate change leads to decreasing bird migration distances. Glob Change Biol 15, 1859-1865.

Ward, M.P., Maftei, D., Apostu, C., Suru, A., 2008. Environmental and anthropogenic risk factors for highly pathogenic avian influenza subtype H5N1 outbreaks in Romania, 2005- 2006. Vet Res Commun $32,627-634$.

Webster, R.G., 2004. Wet markets--a continuing source of severe acute respiratory syndrome and influenza? Lancet 363, 234-236.

Webster, R.G., Govorkova, E.A., 2006. H5N1 influenza--continuing evolution and spread. N Engl J Med 355, 2174-2177.

Wu, X., Tian, H., Zhou, S., Chen, L., Xu, B., 2014. Impact of global change on transmission of human infectious diseases. Sci China Earth Sci 57, 189-203.

Xu, B., Gong, P., Biging, G., Liang, S., Seto, E., Spear, R., 2004. Snail density prediction for schistosomiasis control using IKONOS and ASTER images. Photogramm Eng Remote Sensing 70, 1285-1294.

Xu, B., Gong, P., Seto, E., Liang, S., Yang, C., Wen, S., Qiu, D., Gu, X., Spear, R., 2006. A spatial-temporal model for assessing the effects of intervillage connectivity in schistosomiasis transmission. Ann Assoc Am Geogr 96, 31-46.

Yamamoto, Y., Nakamura, K., Yamada, M., Mase, M., 2010. Persistence of avian influenza virus (H5N1) in feathers detached from bodies of infected domestic ducks. Appl Environ Microbiol 76, 5496-5499. 


\section{Figure legends}

Figure 1. Comparison of the 12 predicted bird distributions from January to December 2005-2009 by Maximum Entropy model. The probability is coded from low values, in light grey, to high values, in dark grey. The 'K-folds' cross-validation approach was used to assess the accuracy of the model. The receiver operating characteristic (ROC) of the 12 models ranged from 0.892 to 0.960 , and the average ROC was 0.926 .

Figure 2. The permutation importance of variables by jack-knife of the area under the curve (AUC) for predicted bird distribution in migration. The importance of climate variables to bird migration varied by season.

Figure 3. Comparison of the 12 risk maps describing HPAI H5N1 outbreaks in migratory birds from January to December 2005-2009 by Maximum Entropy model. The probability is coded from low values, in light grey, to high values, in dark grey. The ROC of the 12 models ranged from 0.755 to 0.989 , and the average ROC was 0.938 .

Figure 4. The permutation importance of variables by jack-knife of AUC for predicted outbreaks of HPAI H5N1 in migratory birds. The importance of climate variables to outbreaks of HPAI H5N1 in migratory birds varied by season.

Figure 5. The risk map of HPAI H5N1 outbreaks in migratory birds overlaid with the predicted distribution of migratory birds. The probability is coded from low values, in dark blue, to high values, in dark red. 
Figure 6. The predicted risk map of HPAI H5N1 outbreaks in migratory birds overlaid with the predicted distribution of migratory birds for 2030 based on agreement of 20 global climate models. The probability is coded from low values, in dark blue, to high values, in dark red. 
Table 1 Summary of the statistical analysis of model performance

\begin{tabular}{lllll}
\hline & \multicolumn{2}{c}{ Migration } & \multicolumn{2}{c}{ Outbreak } \\
\cline { 2 - 5 } & AUC & SD & AUC & SD \\
\hline Jan & 0.960 & 0.011 & 0.930 & 0.070 \\
Feb & 0.946 & 0.022 & 0.964 & 0.011 \\
Mar & 0.939 & 0.014 & 0.963 & 0.042 \\
Apr & 0.906 & 0.019 & 0.957 & 0.049 \\
May & 0.908 & 0.018 & 0.919 & 0.062 \\
Jun & 0.892 & 0.021 & 0.755 & 0.233 \\
Jul & 0.911 & 0.019 & 0.989 & 0.013 \\
Aug & 0.914 & 0.022 & 0.981 & 0.017 \\
Sep & 0.911 & 0.012 & - & - \\
Oct & 0.917 & 0.006 & 0.951 & 0.058 \\
Nov & 0.949 & 0.018 & 0.928 & 0.074 \\
Dec & 0.957 & 0.012 & 0.986 & 0.012 \\
\hline
\end{tabular}


Table 2 High probability of the variables related to presence of migratory birds in response curves

\begin{tabular}{|c|c|c|c|c|c|c|c|}
\hline & $\begin{array}{c}\text { maximum } \\
\text { temperature } \\
\left({ }^{\circ} \mathrm{C}\right)^{*}\end{array}$ & $\begin{array}{c}\text { minimum } \\
\text { temperature } \\
\left({ }^{\circ} \mathrm{C}\right)\end{array}$ & $\begin{array}{c}\text { mean } \\
\text { temperature } \\
\left({ }^{\circ} \mathrm{C}\right)\end{array}$ & $\begin{array}{c}\text { air } \\
\text { pressure } \\
(\mathrm{hPa})\end{array}$ & $\begin{array}{c}\text { specific } \\
\text { humidity } \\
\left(\mathrm{gm}^{-3}\right)\end{array}$ & $\begin{array}{l}\text { precipitation } \\
(\mathrm{mm})\end{array}$ & radiation $\left(\mathrm{Wm}^{-2}\right)$ \\
\hline Jan & & $\begin{array}{c}-18--14, \\
12-17\end{array}$ & & & & & 5200 \\
\hline Feb & & $-15--1,15-19$ & & 570 & $5.8-6.2$ & & \\
\hline Mar & & $-11-0,19-24$ & & & $6.5-7$ & & \\
\hline Apr & & $-8--3$ & $-1-2$ & & & & $9500-115000$ \\
\hline May & & & $1-2,20-25$ & & $11.5-12.5$ & & 10200 \\
\hline Jun & $12-15,30-37$ & & & 560 & & & 10200 \\
\hline Jul & $12-15,30-35$ & & & $550-560$ & & & \\
\hline Aug & & & & & & $100-120$ & $9900-11500$ \\
\hline Sep & & & & $540-560$ & $6.5-8.2$ & $10-50$ & $5600-5700$ \\
\hline Oct & & & $-3-0,32$ & & & $10-50$ & $5800-7000$ \\
\hline Nov & $-5-5,17-25$ & $-12--11,18-19$ & & & & & $5000-5200$ \\
\hline
\end{tabular}


12-17

* two ranges of temperature indicate that the migratory birds distributed in different temperature zones 
Table 3 Variables associated with high risk of HPAIV H5N1 outbreak in migratory birds in response curves

\begin{tabular}{|c|c|c|c|c|c|c|c|}
\hline & $\begin{array}{c}\text { maximum } \\
\text { temperature } \\
\left({ }^{\circ} \mathrm{C}\right)\end{array}$ & $\begin{array}{c}\text { Minimum } \\
\text { temperature } \\
\left({ }^{\circ} \mathrm{C}\right)\end{array}$ & $\begin{array}{c}\text { mean } \\
\text { temperature } \\
\left({ }^{\circ} \mathrm{C}\right)\end{array}$ & $\begin{array}{c}\text { air pressure } \\
(\mathrm{hPa})\end{array}$ & $\begin{array}{l}\text { specific } \\
\text { humidity } \\
\left(\mathrm{gm}^{-3}\right)\end{array}$ & $\begin{array}{c}\text { precipitation } \\
(\mathrm{mm})\end{array}$ & $\begin{array}{l}\text { radiation } \\
\left(\mathrm{Wm}^{-2}\right)\end{array}$ \\
\hline Jan & & & & & 3.2 & $40-60$ & \\
\hline Feb & & & 2 & & & & $2800-3200$ \\
\hline Mar & & -2 & & & & & $4000-4100$ \\
\hline Apr & 19 & -1 & & & & & \\
\hline May & & & & & & & $10500-11300$ \\
\hline \multicolumn{8}{|l|}{ Jun } \\
\hline Jul & & & & 980 & 8.8 & $40-60$ & 7200 \\
\hline Aug & & & 19 & & 7.2 & $40-60$ & 10200-10300 \\
\hline Oct & & & & 1010 & & & \\
\hline Nov & & & 32 & $1000-1026$ & & & \\
\hline Dec & & & & $1000-1026$ & & & \\
\hline
\end{tabular}



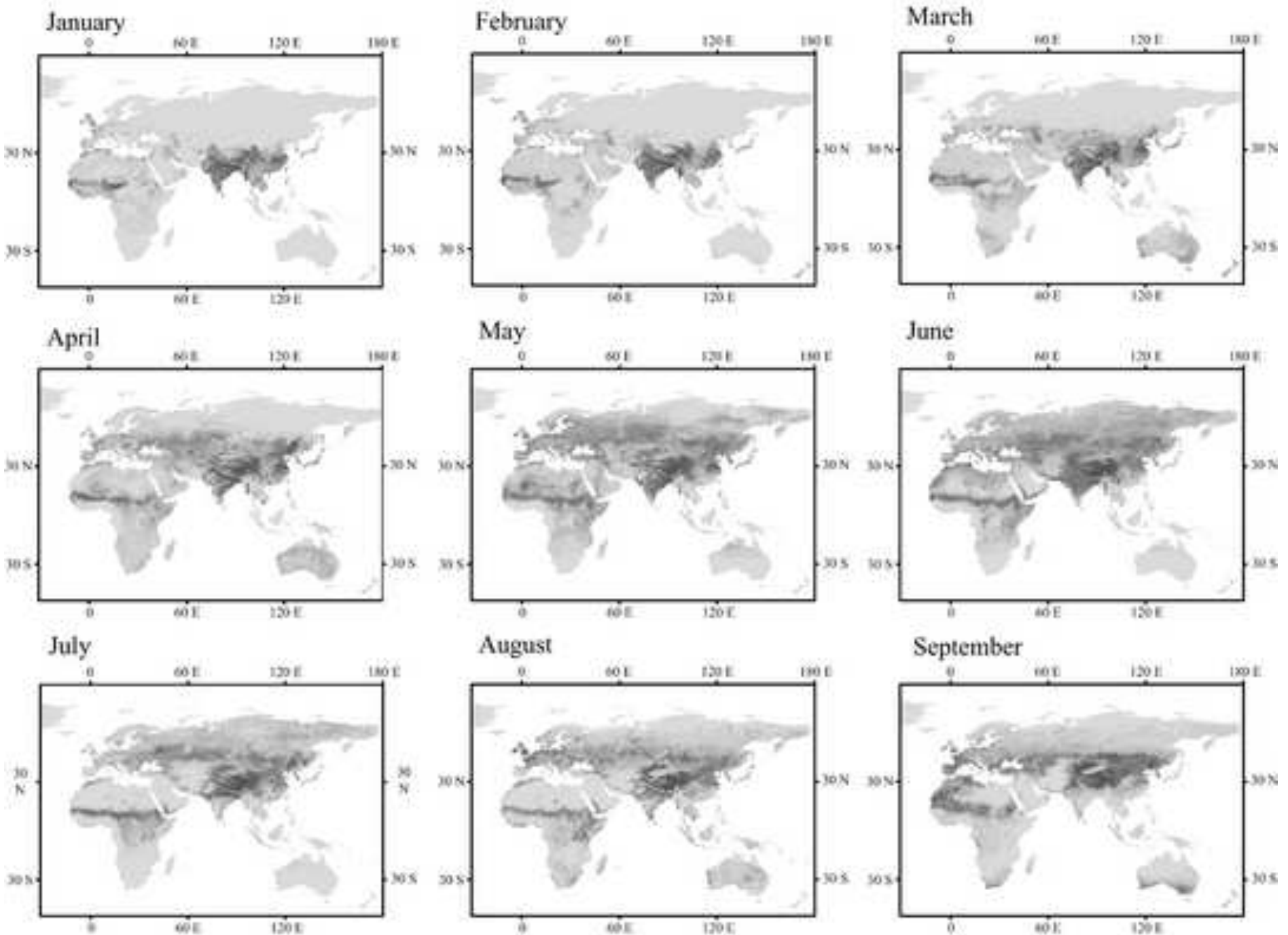

August

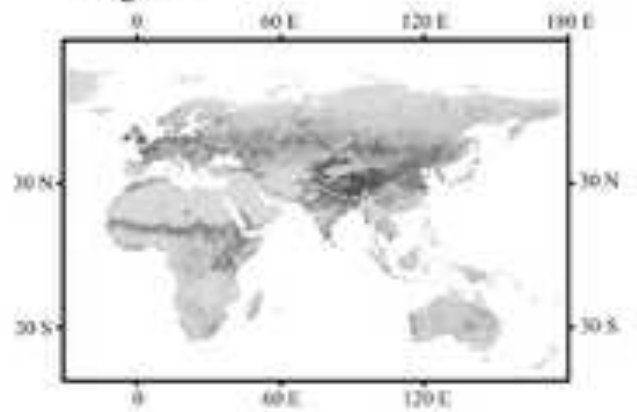

September
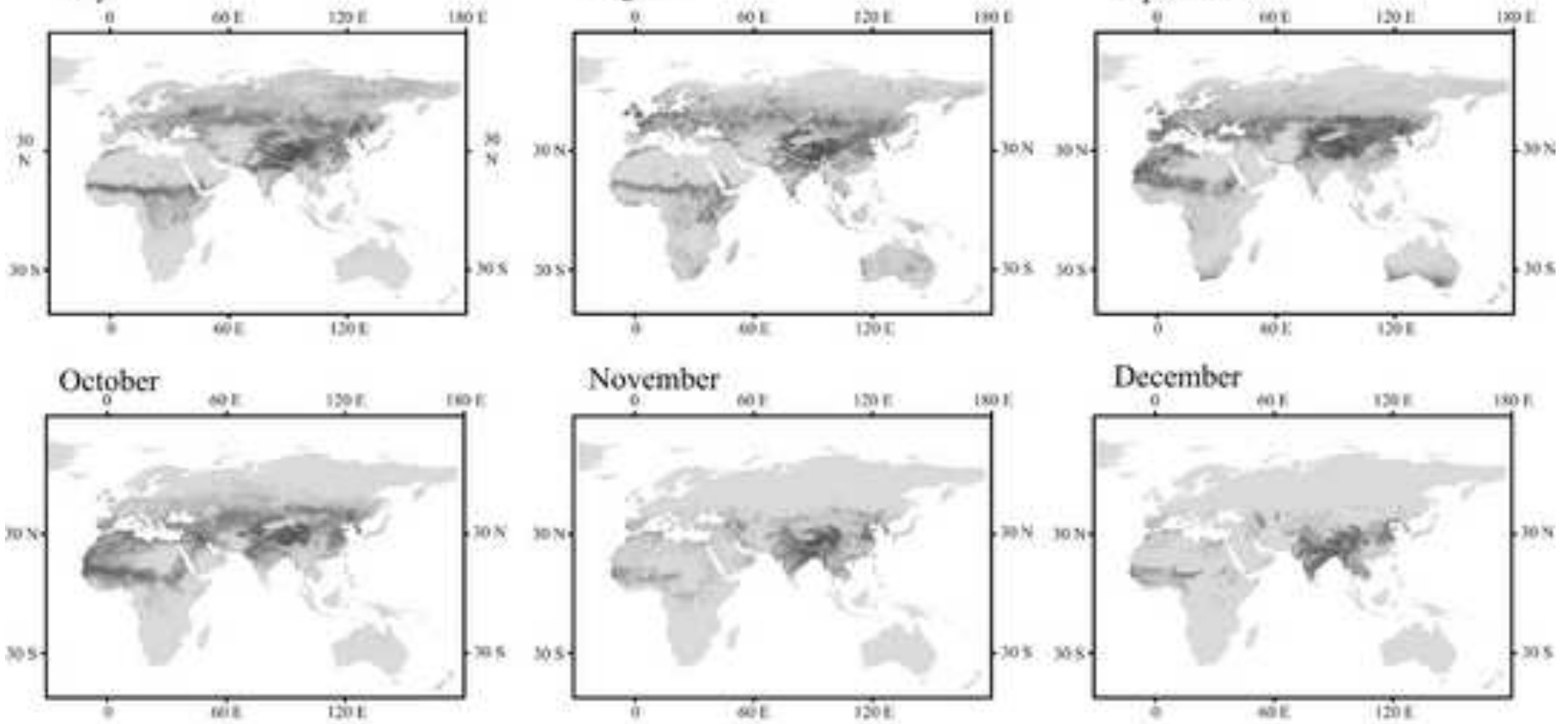

November

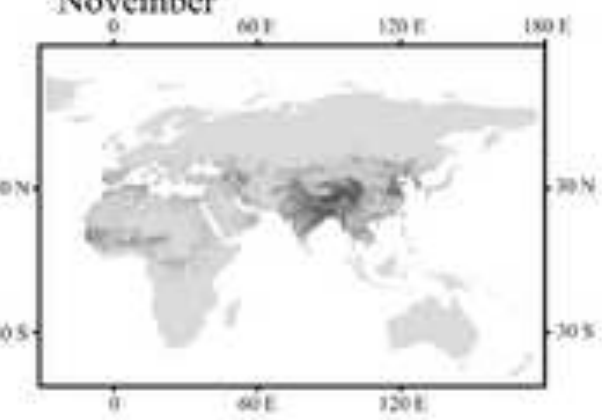

December

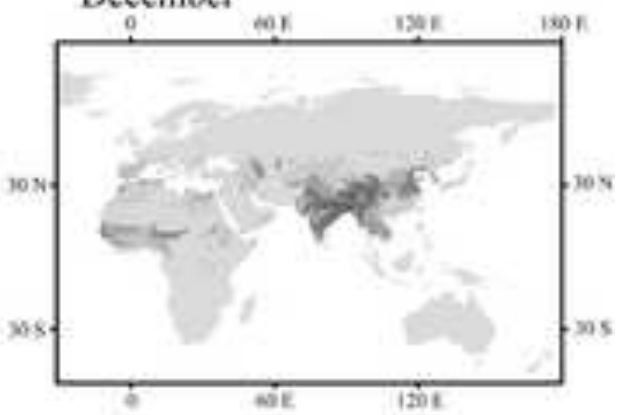

Predicted bird distribution

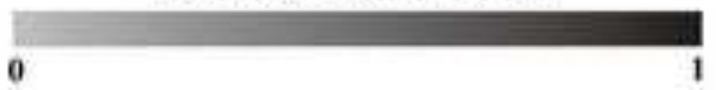




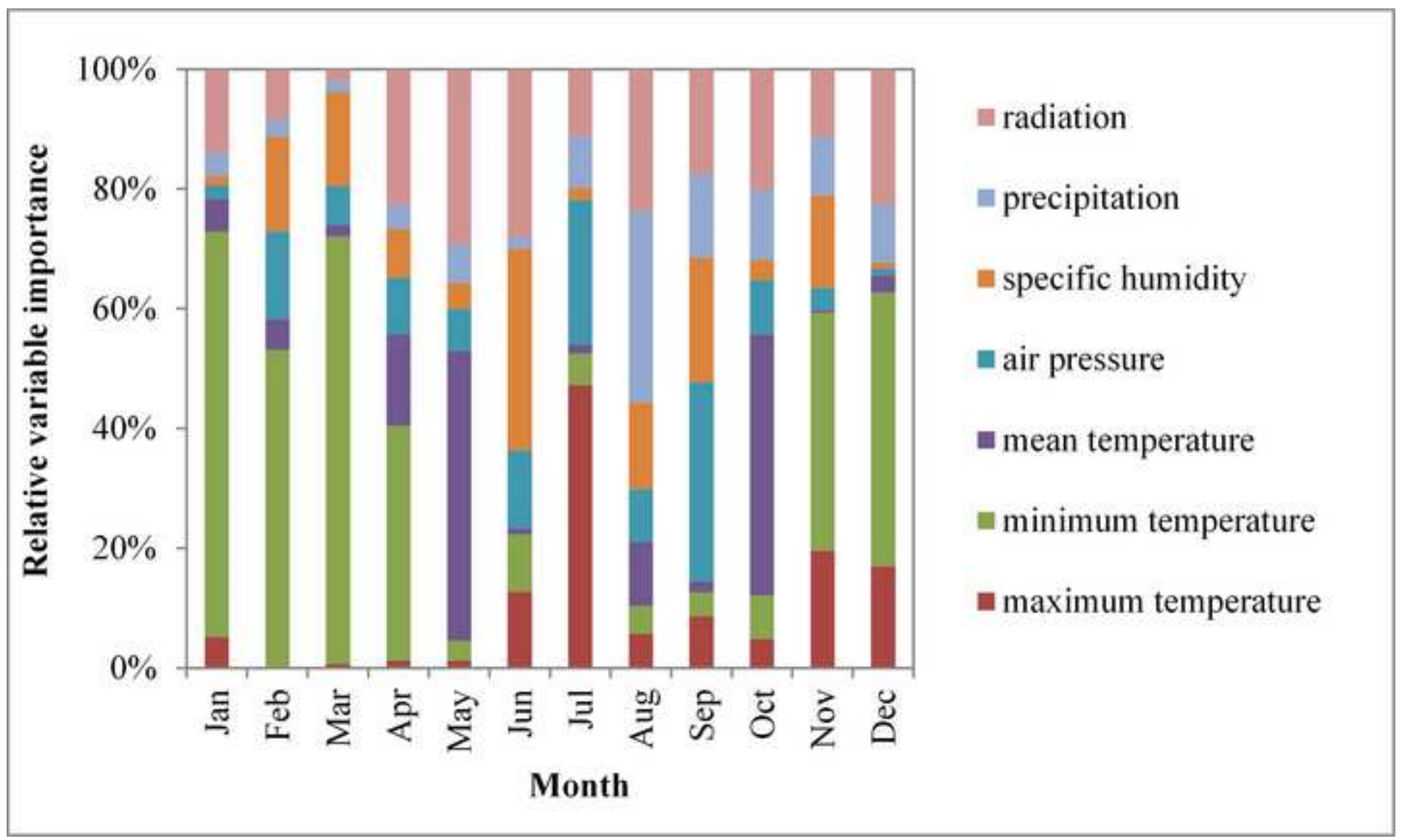


Figure 3
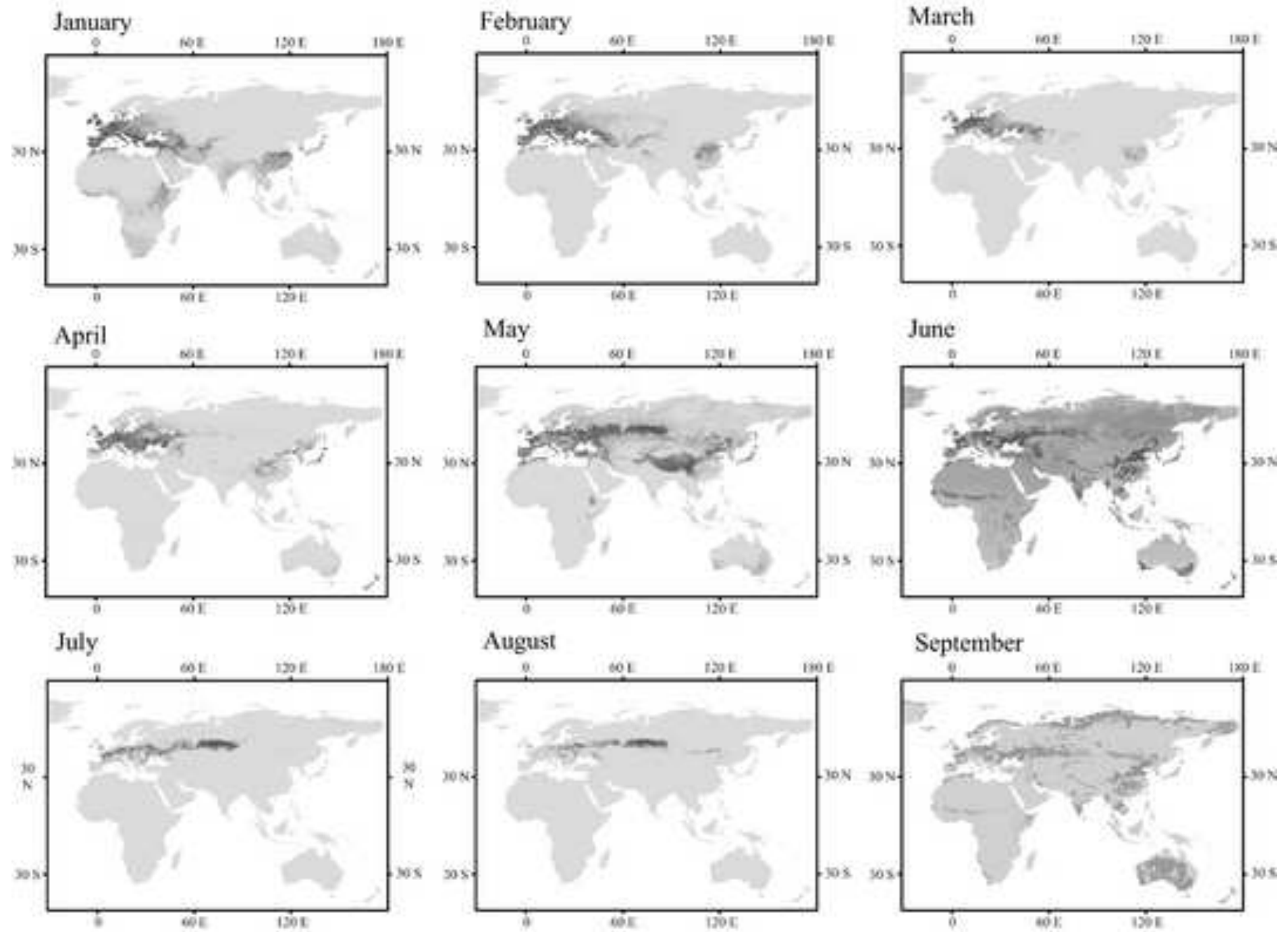

August

September
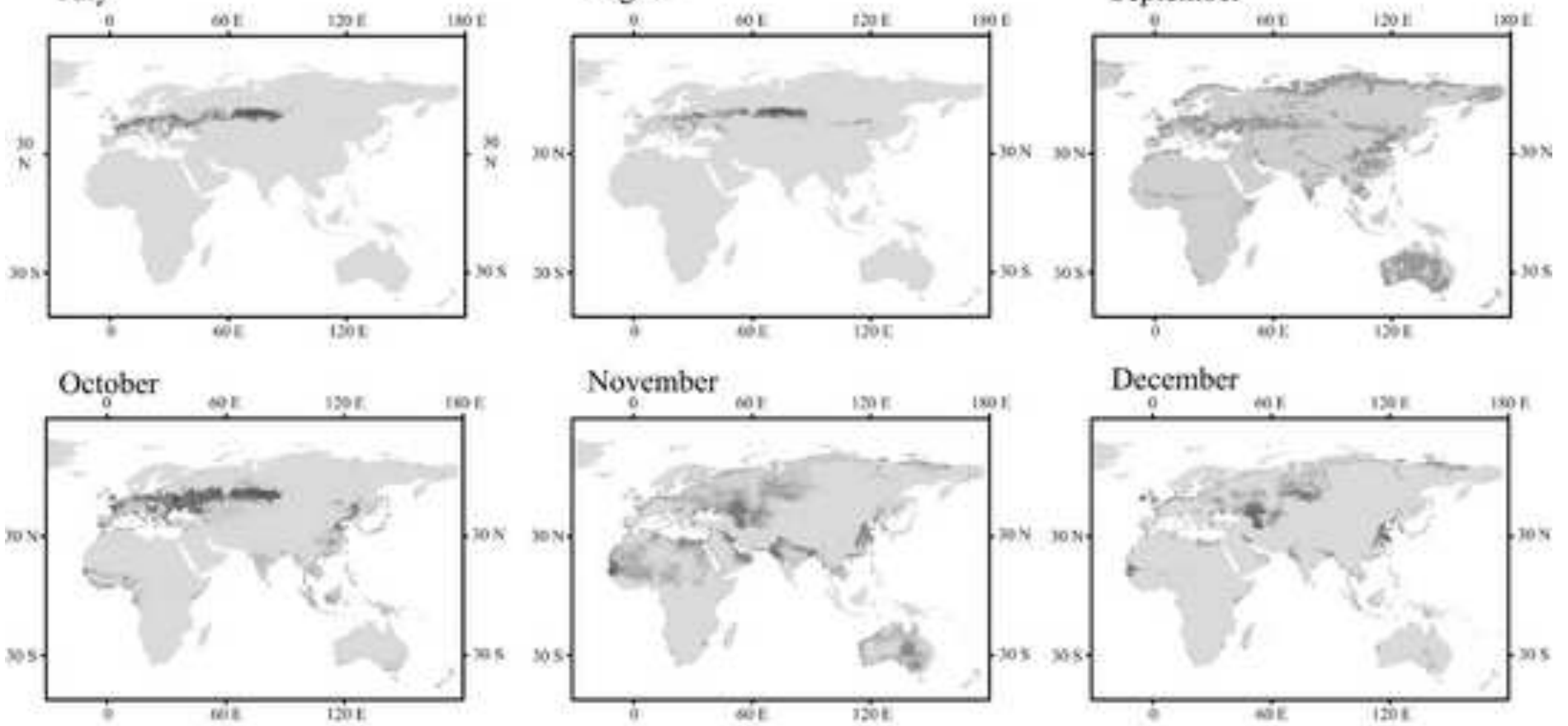

November

December

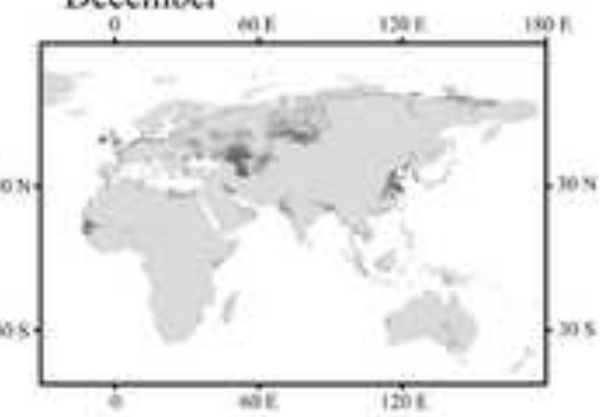

Predicted risk of HPAIV H5N1

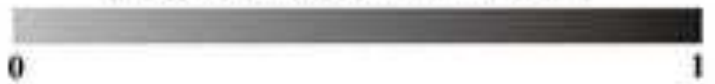




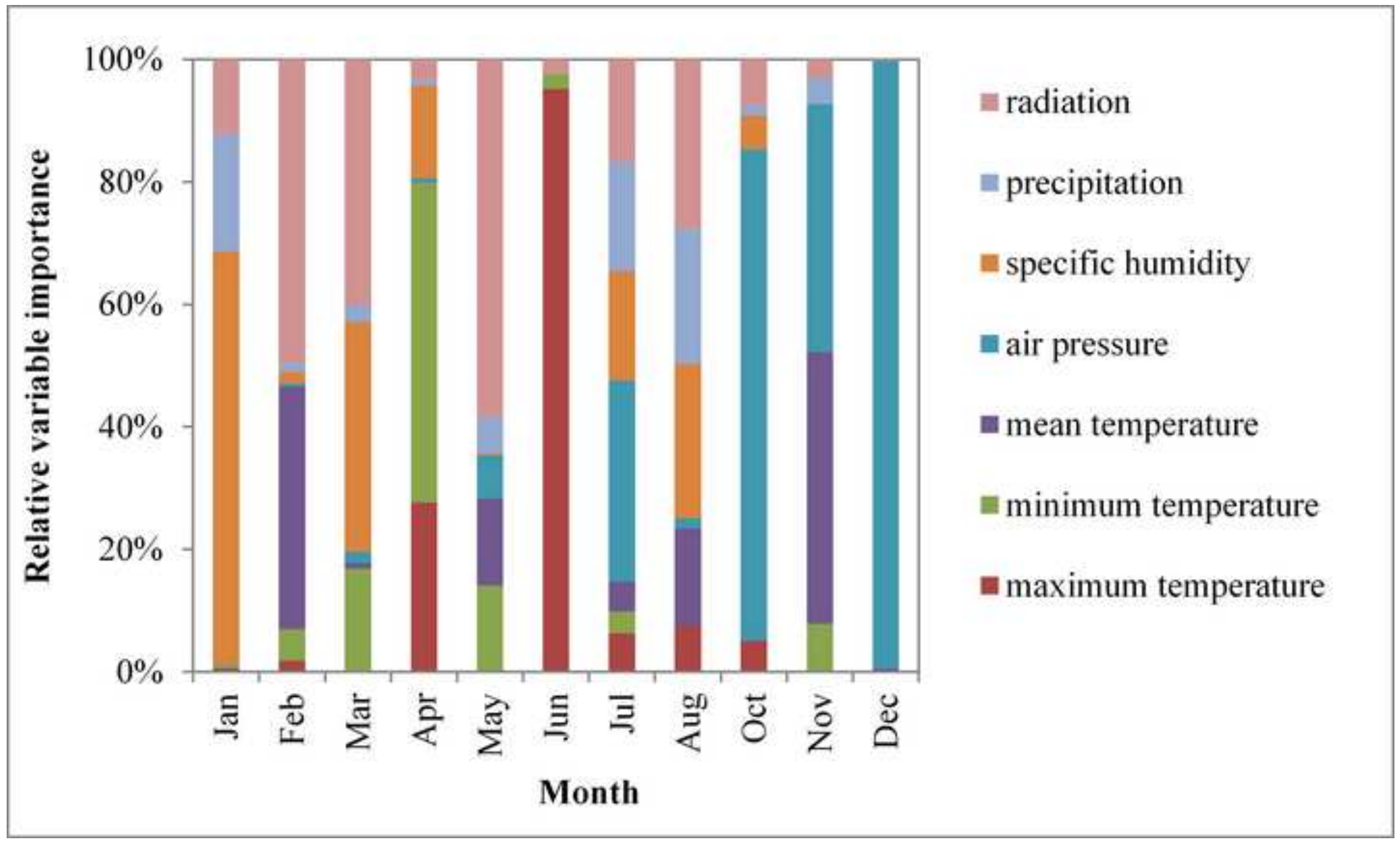



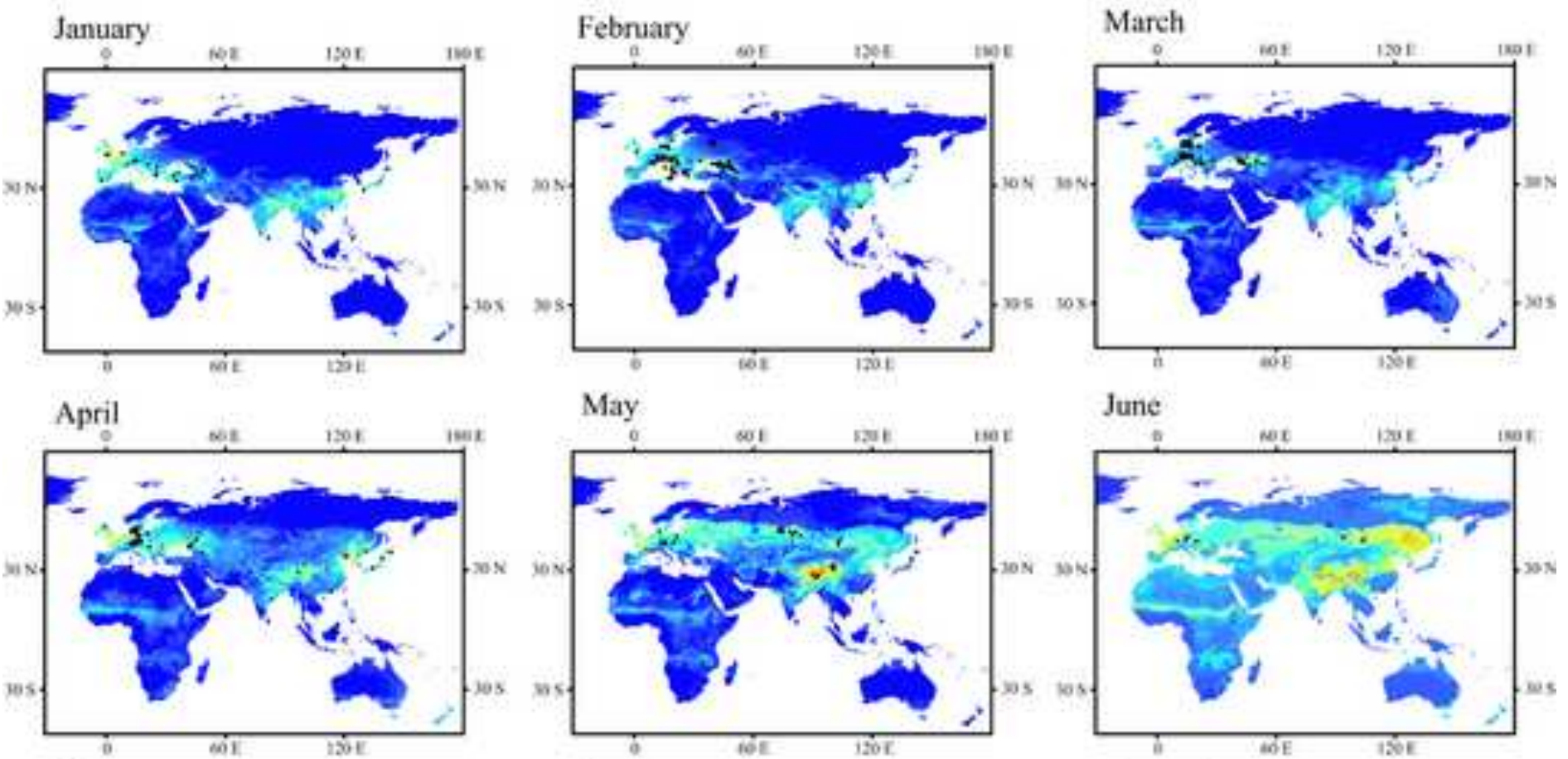

July

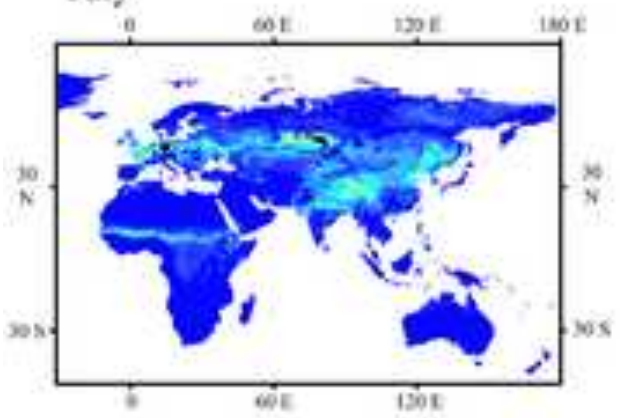

August

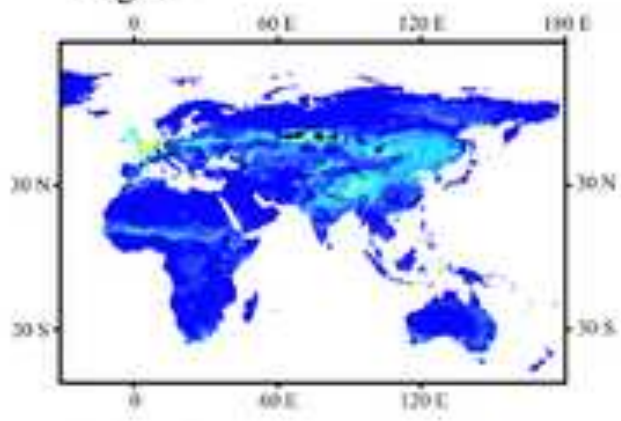

September
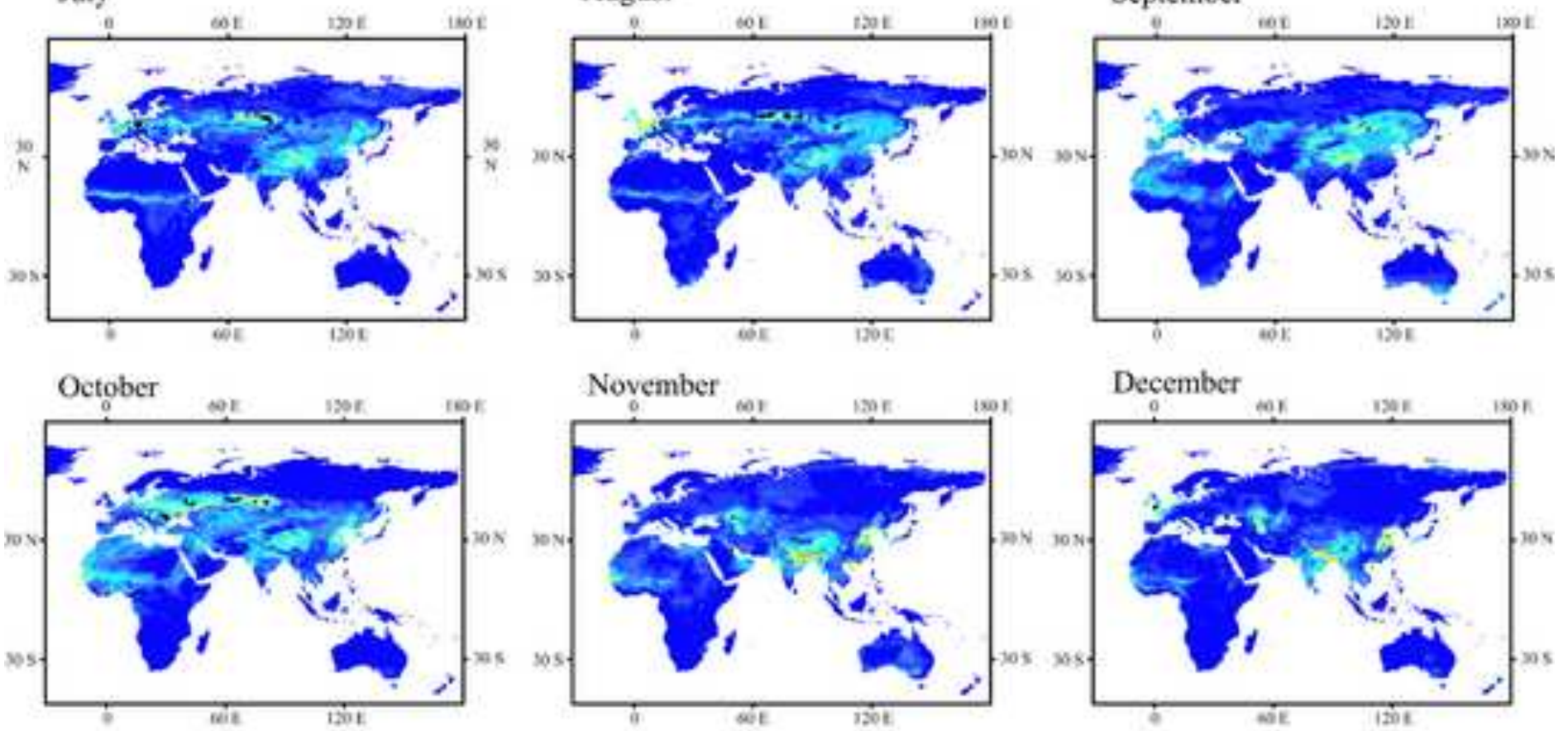

November

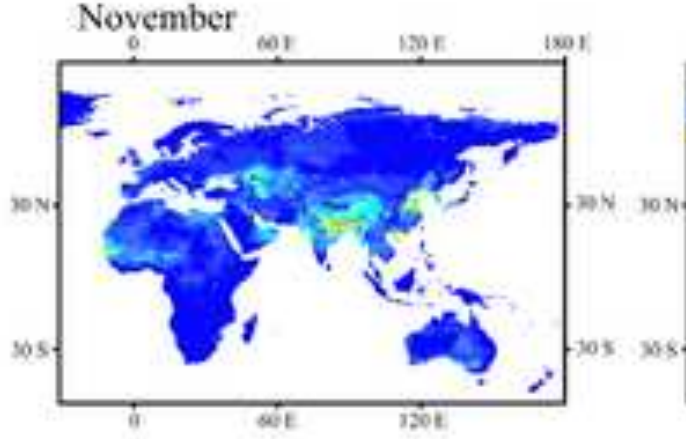

December

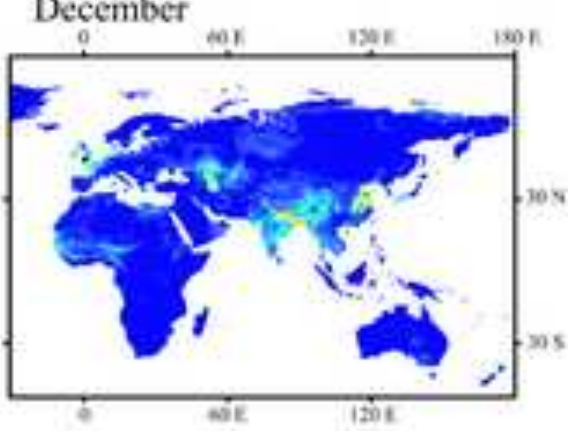

Predicted Risk

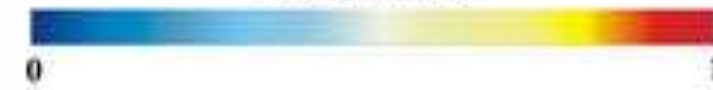

- HPAIV H5NI infection in wild birds 

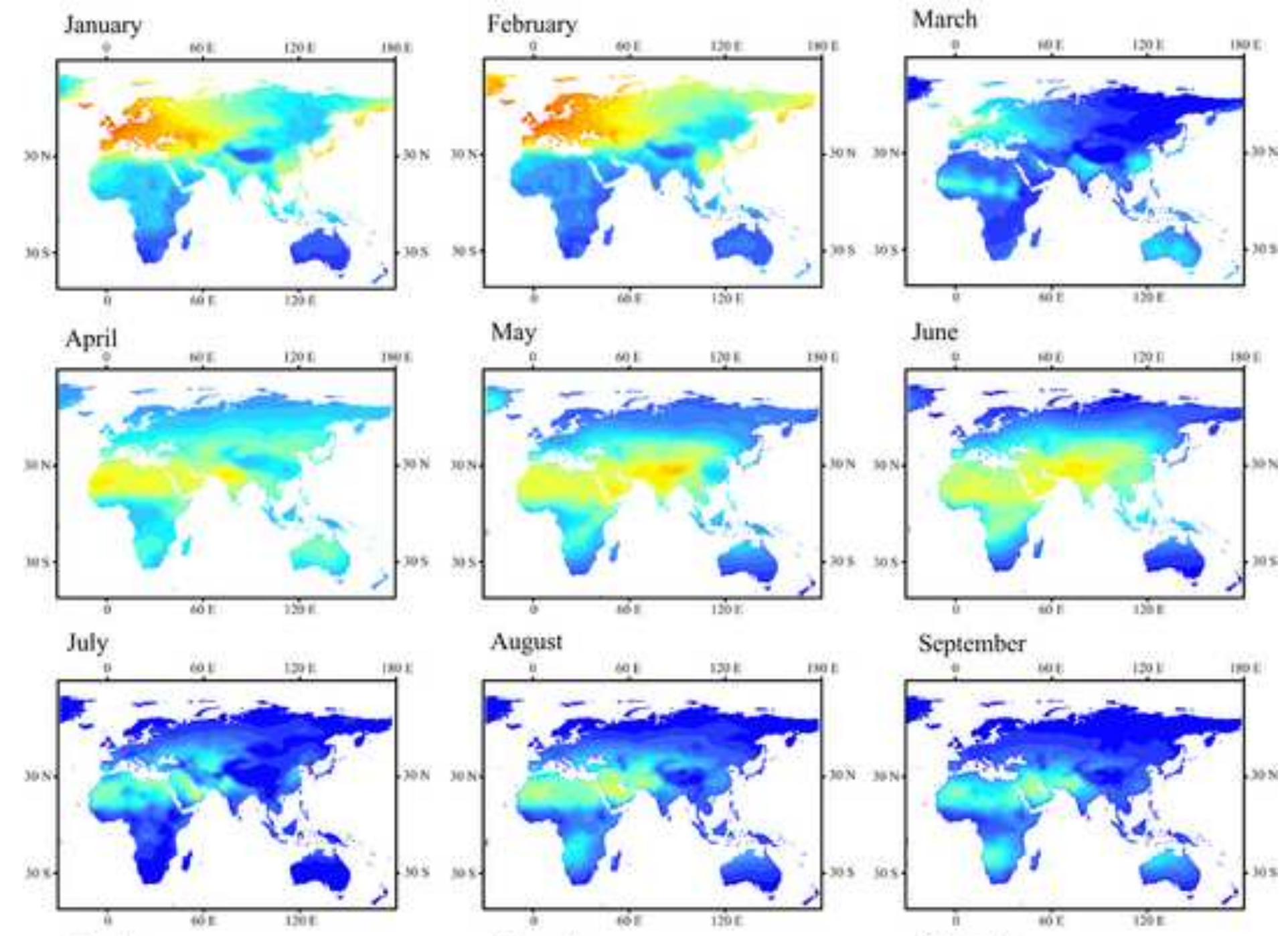

September

October

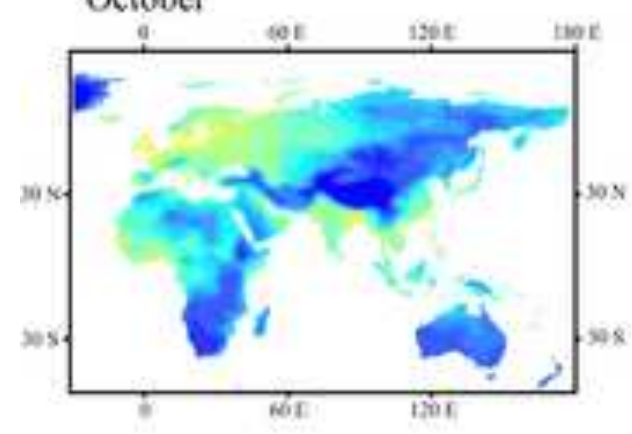

November
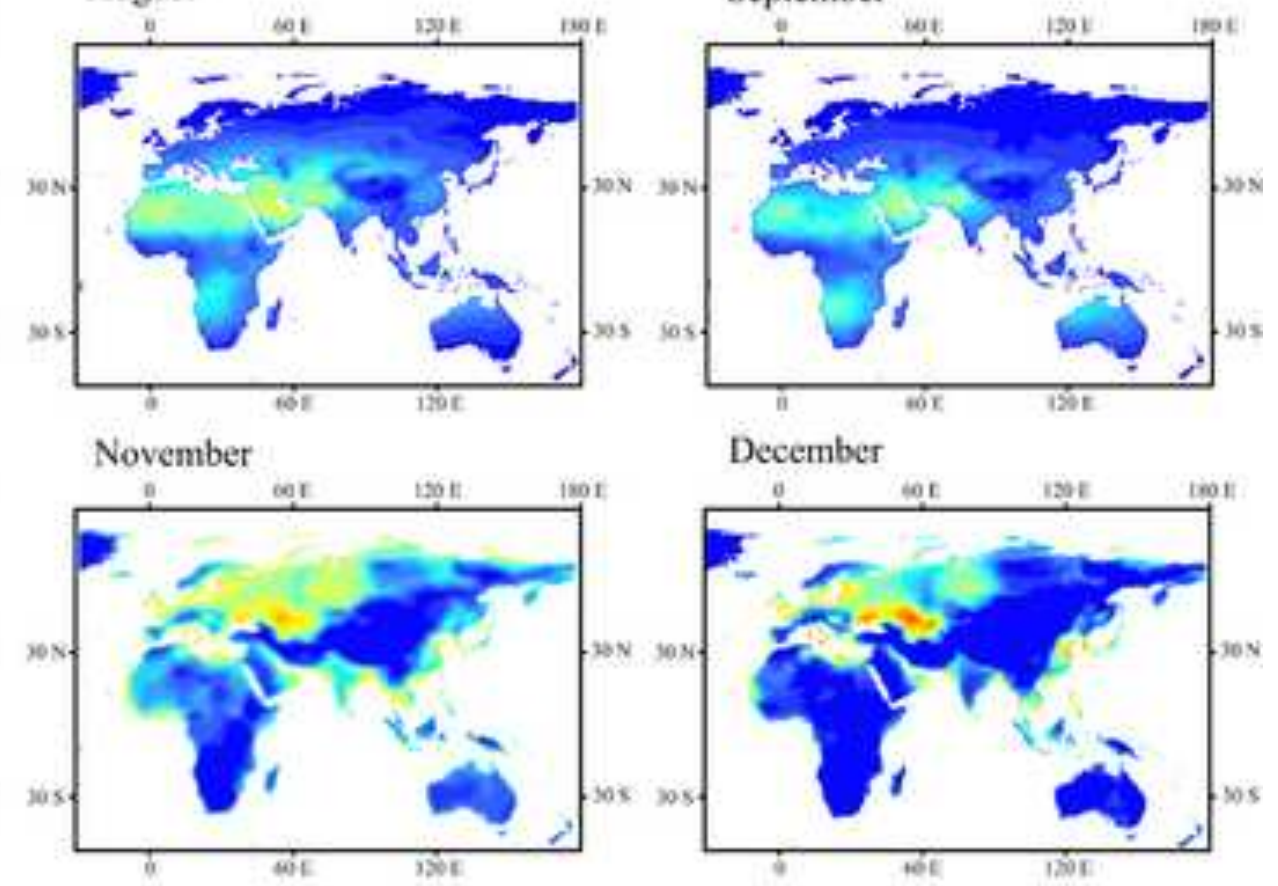

December

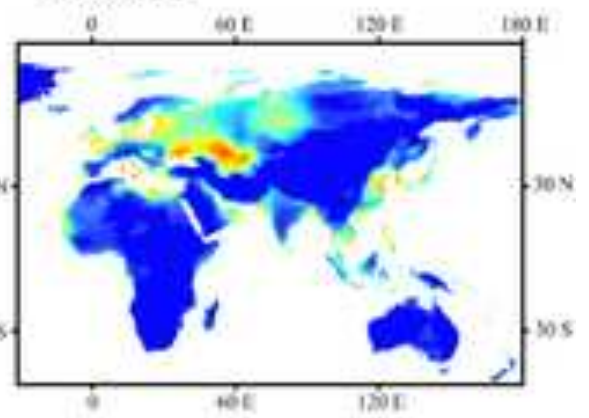

Predicted risk 